\title{
BYZANTINE STUDIES IN VOLGOGRAD. AN EXCURSION INTO HISTORY AND BIBLIOGRAPHY
}

\author{
Nikolay D. Barabanov \\ Volgograd State University, Volgograd, Russian Federation \\ Vladimir A. Zolotovskiy \\ Volgograd State University, Volgograd, Russian Federation \\ Anastasiya V. Zykova \\ Volgograd State University, Volgograd, Russian Federation
}

\begin{abstract}
The proposed essay is a publication of bibliographic information about scientific works (dissertations, monographs, collections of scientific articles, periodicals) concerning the Byzantine history and published in Volgograd or with the direct participation of Volgograd researchers. The origin and development of studying the Byzantine history in Volgograd is associated with two higher educational institutions - Volgograd State University and Tsaritsyn Orthodox University of St. Sergius of Radonezh, within the walls of which large and internationally recognized periodicals appeared.

Key words: Byzantine studies in Volgograd, Volgograd State University, Science Journal of VolSU. History. Area Studies. International Relations, Tsaritsyn Orthodox University, The World of Orthodoxy, V.V. Kuchma,
\end{abstract} N.D. Barabanov.

Citation. Barabanov N.D., Zolotovskiy V.A., Zykova A.V. Byzantine Studies in Volgograd. An Excursion into History and Bibliography. Vestnik Volgogradskogo gosudarstvennogo universiteta. Seriya 4. Istoriya. Regionovedenie. Mezhdunarodnye otnosheniya [Science Journal of Volgograd State University. History. Area Studies. International Relations], 2020, vol. 25, no. 6, pp. 317-332. (in Russian). DOI: https://doi.org/10.15688/ jvolsu4.2020.6.26

УДК 930.1(091:470.45)

\section{ВИЗАНТИНОВЕДЕНИЕ В ВОЛГОГРАДЕ. ЭКСКУРС В ИСТОРИЮ И БИБЛИОГРАФИЮ}

\author{
Николай Дмитриевич Барабанов \\ Волгоградский государственный университет, г. Волгоград, Российская Федерация \\ Владимир Алексеевич Золотовский \\ Волгоградский государственный университет, г. Волгоград, Российская Федерация

\section{Анастасия Валерьевна Зыкова} \\ Волгоградский государственный университет, г. Волгоград, Российская Федерация
}

Аннотация. Предлагаемый очерк представляет собой публикацию библиографической информации о научных трудах (диссертации, монографии, сборники научных статей, периодические издания), касающихся византийской истории и изданных в Волгограде или при непосредственном участии волгоградских исследователей. Зарождение и развитие изучения истории Византии в Волгограде связано с двумя высшими учеб- 
ными заведениями - Волгоградским государственным университетом и Царицынским Православным университетом им. преп. Сергия Радонежского, в стенах которых появились крупные и международно признанные периодические издания. Текстовая часть работы проделана Н.Д. Барабановым, сведения по «Миру Православия» систематизированы В.А. Золотовским, информация по отдельным сборникам и «Вестнику ВолГУ. Серия 4» подготовлена А.В. Зыковой.

Ключевые слова: византиноведение в Волгограде, Волгоградский государственный университет, Вестник ВолГУ. Серия 4, Царицынский Православный университет, Мир Православия, В.В. Кучма, Н.Д. Барабанов.

Цитирование. Барабанов Н. Д., Золотовский В. А., Зыкова А. В. Византиноведение в Волгограде. Экскурс в историю и библиографию // Вестник Волгоградского государственного университета. Серия 4, История. Регионоведение. Международные отношения. - 2020. - Т. 25, № 6. - C. 317-332. - DOI: https://doi.org/ 10.15688/jvolsu4.2020.6.26

Введение. Предлагаемая вниманию читателя статья имеет целью публикацию библиографической информации о научных работах, которые увидели свет на страницах волгоградских периодических изданий, а также отдельных тематических сборников, в период с момента зарождения византиноведческих штудий в городе до наших дней. Нельзя сказать, что исследования волгоградских византинистов за почти полувековой период были совершенно обойдены вниманием. Информация о них проникала в научную среду через некоторые отечественные $[4 ; 1 ; 2]$ и даже зарубежные [5] издания. Однако указанные публикации не выходили за пределы кратких заметок, ограниченных хронологическими рамками и описанием отдельных сборников статей. В данном случае ситуация иная мы пытаемся представить если не полный, то максимально информативный перечень трудов касающихся византийской истории и изданных в Волгограде.

Появление этой экзотической для Нижнего Поволжья науки в городе на Волге связано с появлением в нем новых учебных заведений. Вскоре после создания в 1967 г. Высшей следственной школы при МООП РСФСР в ней появился уникальный преподаватель. Это был историк, яркий представитель уральской школы византиноведения, ученик профессора М.Я. Сюзюмова, В.В. Кучма (19382011 гг.), который в труднейших для провинциальной науки условиях продолжил исследования по военной истории и полемологии в Византии. В 1995 г. Владимир Васильевич стал работать на юридическом факультете Волгоградского государственного университета, где оставался до конца своих дней, принимая активное участие в научной жизни вуза. Тру- ды В.В. Кучмы широко известны (список: [3]) и не нуждаются в данном случае в особой характеристике.

Новый импульс в развитии византиноведения в Волгограде связан с созданием в 1980 г. Волгоградского государственного университета, в стенах которого через год появился один из авторов этой публикации - Н.Д. Барабанов, также представитель уральской школы византиноведения и ученик М.Я. Сюзюмова. С этого времени студенты ВолГУ стали писать курсовые и дипломные работы по разным проблемам истории Византии. Интерес к византиноведению возрастал, что привело к открытию аспирантуры. Следует отметить, что через эту форму обучения в университете прошло около десятка энтузиастов, работы которых встречаются в публикуемых далее списках. К сожалению, по совокупности причин не все они смогли защитить диссертации и связать свою жизнь с наукой и преподаванием. Отметим те исследования, которые были успешно завершены под руководством Н.Д. Барабанова. В 2006 г. А.А. Пржегорлинский защитил диссертацию на тему «Идейно-политические процессы в Византии на рубеже XIII-XIV вв.: митрополит Феолипт Филадельфийский и его наследие», которая позже была опубликована (Пржегорлинский, А., священник. Византийская церковь на рубеже XIII-XIV вв. Деятельность и наследие св. Феолипта, митрополита Филадельфийского / священник А. Пржегорлинский ; науч. ред. Н.Д. Барабанов. - СПб. : Алетейя, 2011. 240 с. - (Серия «Византийская библиотека. Исследования»). В 2009 г. была защищена диссертация B.A. Золотовским по теме «Военная организачия Византии при первых Палеологах (1259-1328 г2.): принцчипы 
формирования и сферы функиионирования», которая со временем также была издана: Золотовский, В.А. Армия и общество Византийской империи: особенности военной организации Византии раннепалеологовского периода / В.А. Золотовский. - Saarbrucken : LAP LAMBERT Academic Publishing, 2013. В 2016 г. успешно защитил диссертацию E.B.Стельник по теме "Путешествие в мир иной»: образ Харона/Хароса в культуре $и$ религиозном сознании византийского общества». В настоящее время исследование по политической и военной истории Византии на рубеже XIII-XIV вв. готовит к защите П.И. Лысиков. Появление в ВолГУ группы византинистов - единомышленников привело к активизации издательской деятельности, которая сначала выражалась в подготовке тематических сборников по истории Византии (Власть, общество и церковь в Византии: сборник научных статей; $\Sigma$ ТРАТНГО $\Sigma$ : сборник статей в честь Владимира Васильевича Кучмы; ПО $\Lambda$ ЕМО $О Г О$ статей памяти профессора В.В. Кучмы), а затем, после успешного проведения в 2015 г. международной конференции «Мир Православия. Византийская цивилизация и ее наследие», к рождению идеи посвящать византиноведческим проблемам один из выпусков Вестника ВолГУ. Содержание сборников и византийских выпусков Вестника представлено в данной работе.

Еще одно учебное заведение Волгограда, в котором уделялось большое внимание византиноведческой тематике, это Царицынский Православный университет им. преп. Сергия Радонежского, к сожалению, уже завершивший свою историю. Процесс развития в Волгограде духовного образования был труден. Начало ему положил тогда еще архиепископ Герман, открывший 4 ноября 1991 г. экстраординарное одногодичное духовное училище, напоминавшее по уровню подготовки священнослужителей «курс молодого бойца». Отметим его положительную роль в том смысле, что вокруг училища началось объединение преподавателей волгоградских вузов, прежде всего, историков и филологов, готовых сотрудничать с молодой епархией. Следует отметить, что уже на этой стадии в программе училища важное место занимало изуче- ние церковной истории с полным курсом истории византийской церкви. Стимулом для дальнейшего развития духовной школы стало проведение в Волгограде в сентябре 1992 г. церковно-научной конференции «Преподобный Сергий Радонежский и современный православный университет». Идея создания именно такого учебного заведения недолго бродила по умам и кабинетам - уже в ноябре того же года архиепископ Герман по благословению патриарха Алексия II подписал указ о создании Царицынского православного университета имени преподобного Сергия Радонежского. В сентябре 1993 г. начались занятия на трех факультетах - богословском, пастырско-педагогическом и экологическом. Жизненный путь учебного заведения был непростым, но вполне естественные трудности периода становления были постепенно преодолены. Стоит напомнить, что в Царицыне Сталинграде - Волгограде, как и в случае с византиноведением, не было никаких традиций ни богословского образования, ни церковно-исторической науки. Именно православный университет создал ту среду, в которой стало возможно развитие этих дисциплин. С самого начала на богословском факультете большое внимание уделялось науке - как в аспекте качества преподавания, так и в аспекте разработки конкретных богословских и церковно-исторических сюжетов, в частности, в рамках византиноведения. В программе стоял курс «Византология», преподавался древнегреческий язык, готовились курсовые и дипломные работы на темы византийской церковной истории. Несколько дипломных сочинений по истории византийской церкви были затем преобразованы в кандидатские диссертации и успешно защищены в МДА. Стимулом для активизации научной деятельности преподавателей и студентов стало регулярное проведение конференций, а затем возник вопрос о публикации результатов исследований. Первый, можно сказать, очень робкий сборник, назывался «Православие: вехи истории» и увидел свет в 1996 г. Опыт его издания показал, что среди историков и филологов - преподавателей волгоградских вузов, занимающихся наукой, существует устойчивый интерес к Православию, его истории и культуре. Более того, выяснилось, что этот интерес может 
быть реализован в создании исследований вполне достойного качества. В итоге родилась идея серийного издания, что привело к появлению в 1997 г. первого выпуска «Мира Православия». С самого начала работа над изданием осуществлялась в тесном сотрудничестве с ВолГУ, а византийская тематика в аспектах богословия, церковной истории, агиографии занимала в нем важнейшее место. Сборник постепенно набирал силу. Первые тоненькие, «малобюджетные» брошюры сменились солидными томами в твердом переплете. Сложился коллектив постоянных авторов, к которому по мере обретения «Миром Православия» известности в научной среде стали присоединяться исследователи из многих научных учреждений России и ближнего и дальнего зарубежья. Важно, что среди авторов сборника стали постоянно присутствовать выпускники богословского факультета ЦПУ, в том числе занимавшиеся византийским богословием и историей церкви, что, кроме прочего, свидетельствует о качестве их научной подготовки. Синтез духовного и светского образования, осуществлявшийся в Царицынском Православном университете, принес свои плоды. «Мир Православия», византиноведческое содержание которого представлено далее - один из них. Следует особо отметить, что в данной публикации мы оставили информацию о тех разделах и статьях этого издания, которые так или иначе связаны с разными аспектами истории Византии.

\section{ПЕРИОДИЧЕСКИЕ ИЗДАНИЯ}

\section{«Мир Православия»}

\section{7. Выпуск 1}

\section{История Церкви}

Тюленев В.И. История Церкви в описании Лактанция ("De mortibus persecutorum”) [5-8].

Прокопьев С.М. Историческая концепция Оригена в отечественной и зарубежной литературе [9-13].

Священник Николай Станков. Новейшие исследования о деятельности святых равноапостольных Кирилла и Мефодия [14-21].
Барабанов Н.Д. Византийское православие и война: некоторые аспекты отношений [22-31].

Малахов С.Н. О греческой письменной традиции у народов Северного Кавказа в $\mathrm{X}-$ XVII вв. [32-39].

Шевченко B.B. "Спасен заступничеством Богородицы...” (Иосиф Вриенний об осаде Константинополя в 1422 г.) [47-56].

\section{8. Выпуск 2}

\section{История Церкви}

Тюленев В.М. Рассказы Лактанция о битвах и проблема становления церковной историографии [3-8].

Барабанов Н.Д. Приходское православие в Византии по канонам Трулльского собоpa [9-13].

Священник Николай Станков. Современные исследователи о литературной деятельности св. Кирилла-первоучителя славян [14-17].

Медведев И.П. Канонизация св. Григория Паламы: исторический контекст [18-19].

Малахов С.Н. К Истории аланской митрополии Константинопольского патриархата (местонахождение византийской ахохии) [20-24].

Aсташин B.B. Константинопольский патриарх Кирилл Лукарис и шведский канцлер Оксеншерна [25-27].

\section{Bыnуск 3}

\section{История византийской иеркви}

Станков Николай, священник. Споры в историографии о целях хазарской миссии святых равноапостольных Кирилла и Мефодия [21-27].

Малахов С.Н. Христианизация Алании в 912-922 гг. (по письмам Николая Мистика) [28-36].

Барабанов Н.Д. Гилу (Гелло). К реконструкции византийского народного верования [37-45].

Лобова-Костогрызова Л.Ю. Духовное наставничество в Византии: Феолипт Филадельфийский и Ирина-Евлогия Хумнена [46-60]. 
Макаров Д.И. Учение Григория Паламы об очищении человека (по трактату «Три главы о молитве и чистоте сердца») и некоторые параллели в поздневизантийской мистике [61-72].

Асташин B.B. Константинопольский патриарх Кирилл Лукарис о положении греческой Церкви в первой трети XVII в. [73-86].

\section{2. Выпуск 4}

История византийской иеркви

Алимов Д.Е. Первое крещение хорватов [3-21].

Барабанов Н.Д. Традиции публичных жертвоприношений в византийском приходском православии VI-VII вв [22-50].

Пржегорлинский A.A. Арсенитская схизма в изображении св. Феолипта Филадельфийского и личность Феолипта в свете его противостояния арсенитам [51-76].

Михайленко С.В. Роль арсенитов в политической жизни Византии в начале XIV в. [77-102].

Лобовикова К.И. Георгий Лапиф в контексте исихастской дискуссии [103-112].

Коновалов А.А. «Мессалианин» Григорий Палама и «православный». Григорий Акиндин: святой глазами еретика [113-124].

Красиков С.В. Григорий Палама как защитник аристотелевских силлогизмов в теологии [125-130].

Макаров Д.И. О значении слова «космос» в гомилиях св. Григория Паламы [131-140].

\section{Рецензии}

Михайленко С.В. Рец. на кн.: Кривушин И.В. Ранневизантийская церковная историография. - СПб.: Изд-во «Алетейя», 1998. 255 с. - (Серия «Византийская библиотека», раздел «Исследования») [388-395].

\section{4. Выпуск 5}

\section{Христианство в период \\ поздней античности \\ и раннего средневековья}

Прокопьев С.М. Христианство в период поздней античности и раннего средневе- ковья методологические подходы к разработке проблем исторической концепции Оригена [7-23].

Стельник E.B. Топология пути в загробный мир в античных и раннехристианских представлениях [24-50].

Тюленев В.M. Сульпиций Север и судьба церковно-исторического жанра в период раннего средневековья [51-66].

Дряхлов В.Н. Христиане в языческих сообществах раннего средневековья [67-79].

Макаров Д.И. Этюды о раннехристианской и византийской гомилетике на преображение господне (III-XV века). Ч. 1. Св. Кирилл Александрийский как последователь Златоуста [80-89].

\section{История византийской ичеркви}

Барабанов Н.Д. К истории приходского православия в Византии. Материальное положение клира в VII веке по канонам Трулльского собора [90-103].

Бармин А.В. Вероятная причина церковного столкновения 1053-1054 годов [104-109].

Романчук А.М. Агиографические и археологические свидетельства о топографии Херсона (Херсонеса) [110-123].

Пржегорлинский A.A. Антиарсенитские трактаты св. Феолипта Филадельфийского [124-133].

Приложение 1. [134-142]

Приложение 2. [143-162]

Малахов С.Н., Тихонов Н.А. Два византийских штампа из Закубанья [163-172].

Красиков С.В. Платонизм Варлаама Калабрийского [172-190].

\section{Реиензии}

Золотовский В.А. Рец. на кн.: Ко́ $\lambda \iota \alpha-$

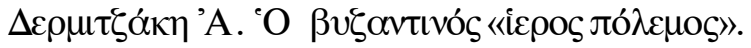

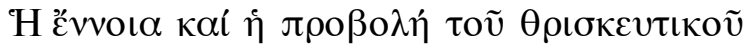

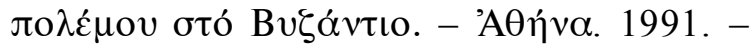
471 c. [517-528].

Пржегорлинский А.А. Рец. на кн.: Макаров Д.И. Антропология и космология св. Григория Паламы (на примере гомилий). СПб.: Изд-во Олега Абышко, 2003. - 544 с. (серия «Библиотека христианской мысли». Исследования) [529-540]. 
Пржегорлинский А.А. Рец. на кн.: Селезнев Н. Христология ассирийской церкви востока. Анализ основных материалов в контексте истории формирования вероучения. M.: Euroasiatica, 2002. - 198 c. [541-555].

\section{6. Выпуск 6}

История раннего христианства

Дряхлов В.Н. Языческое противодействие христианству в Римской империи в конце IV в. (По данным Сократа Схоластика и Сульпиция Севера) [3-11].

Тюленев В.М. Церковно-историческая концепция Руфина Аквилейского [11-25].

Поспелов Д.А., Макаров Д.И. «Слово на святое Воскресение Спасителя нашего Иисуса Христа» св. Иоанна Бейрутского (V в.) [26-35].

Золотова С.Ю. Церковно-государственные отношения в Римской империи в I-IV вв. в трудах А. А. Спасского [36-47].

\section{Православие в Византии}

Баранов В.А. О малоизвестном доиконоборческом учении об «умеренном» иконопочитании [48-60].

Кучма B.B. Война как инструмент государственной политики по «Тактике Льва» (некоторые идеологические и конфессиональные аспекты) [61-75].

Барабанов Н.Д. Почитание икон в Византии и сакральная топография. К постановке проблемы [75-91].

Ларионов А.В. Михаил Пселл как богослов и историк Церкви [91-110].

Брезгунов С.К. Святой Неофит Затворник [110-131].

Власов А.В. Византийская церковь в XIII в. и Лионская уния (1274 г.) [131-166].

Шамгунова T.A. Восприятие войны с варварами византийским монахом (Максим Плануд и Алексей Филантропин) [167-173].

Патрин В.Г. К истории споров о возникновении «молитвы Иисусовой» [173-186].

Пржегорлинский А.А. Исихия как «призвание каждого христианина» в писаниях св. Феолилта и в традиции поздневизантийского исихазма [187-203].
Святой Феолипт, митрополит Филадельфийский Слово на Пятидесятницу. О нисхождении Всесвятого Духа. Перевод и примечания А.А. Пржегорлинского [204-207].

Гаген С.Я. Антилатинская полемика 1234-1258 гг. (Никифор Влеммид и Феодор II Ласкарис) [208-223].

\section{Bыnуск 7}

\section{Православие в истории Византии}

Лурье В.М. Евфимия в Эдессе и Евфимия в Халкидоне: две агиографические легенды на фоне догматических споров [8-40].

Баранов В.А. Иконоборческие споры и богословское значение Нерукотворного Образа [41-57].

Ларионов А.В. (Волгоград-Фессалоники). Ангелология Михаила Пселла (в контексте богословских взглядов церковных писателей XI века) [57-77].

Дунаев А.Г. Православное учение о Евхаристии в контексте паламитских споров [77-98].

Пржегорлинский А.А., священник. Святые Афанасий I Константинопольский и Феолипт Филадельфийский: неприязнь или беспристрастное единомыслие? [99-106]

Барабанов Н.Д. Танец с иконой. К истории почитания образа Одигитрии в Константинополе [107-126].

Золотова С.Ю. Отношение византийского государства к монастырскому землевладению (институт харистикия) в отечественной историографии конца XIX - XX века [127-146].

\section{Bыnуск 8}

Из истории раннего христианства

Дряхлов В.Н. миссионеры и язычники в Галлии в эпоху крушения западной римской империи [3-13].

Стефанов П., архимандрит (Болгария). Женщины в монтанистском духовенстве [13-32].

Православие в истории Византии

Барабанов Н.Д. Праздник рождества св. Иоанна Предтечи в византийской народной традиции [33-66]. 
Коноводов И.В. Интеллектуальный и физический труд в византийских монастырях X-XII вв. [66-81].

Пржегорлинский А.А., священник. Единые уста и единое сердце" пророка Аввакума и святителя Феолипта Филадельфийского: к вопросу о природе богообщения в византийской патристике [81-90].

\section{5. Выпуск 9}

Из истории раннего христианства

Патрин В.Г. Новый образ прп. Антония Великого [3-20].

\section{Византия и ее наследие}

Афиногенов Д.Е. Иоанн Златоуст (?) Об эсхатологическом предназначении римской империи: свидетельство Георгия Монаха [21-30].

Дагрон Ж. Тень сомнения: агиография под вопросом, VI-XI столетия [31-53].

Барабанов Н.Д. След стопы на иконе. Метаморфозы народного почитания священных изображений [54-60].

Вин Ю.Я. Сельская община поздней Византии (XIII-XV вв.) В условиях этнокультурных и конфессиональных конфликтов: опыт исторической реконструкции поздневизантийской общины как внутриэтнической группы [61-99].

Стельник E.B. Харос как ангел в византийском народном богословии [100-117].

Малахов С.Н., Рудниикий Р.Р. Средневековые вотивные железные кресты западного Кавказа (новые находки) [118-131].

\section{Традиичии византийского искусства}

Гаврилович А. О Литературных основах явления пророка Давида и певчих в сцене смерть праведника в трапезной монастыря святого Иоанна Богослова на Патмосе [132-149].

Лещева Я.И. Истоки византийской иконографии вращающегося диска [150-173].

Кутковой В.С. О Синергии творчества в православной культуре [174-188].
Традичии византийского богословия

$$
\text { в России }
$$

Макаров Д.И. О некоторых особенностях тринитарных и христологических воззрений св. Иоанна Кронштадтского в контексте святоотеческой традиции Византии XIXIV вв. Статья первая [189-205].

Сенина T.A. Антропологические воззрения иеросхимонаха Антония (Булатовича) [206-229].

\section{Речензия}

Пржегорлинский А.А. Рец. на кн.: Григорий Богослов. Догматические поэмы / пер. Т.Г. Сидаша. - СПб.: Нестор-История, 2012. 180 с. - (Издательский проект “Квадривиум”, серия "Hellenica") [481-494].

\section{9. Выпуск 10}

\section{Богословские сюжеть}

Пржегорлинский А., священник. Откровение имени божия в служении мессии (к экзегезе ин. 17:26) [3-18].

Патрин В., священник. Полемика с мессалианами в апофтегме Аввы Лукия: социальная роль аскета-молитвенника [19-31].

Неклюдов И., священник. Антропология св. прав. Николая Кавасилы в свете богословия творения [32-42].

\section{Византия: иерковь и общество}

Вин Ю.Я. Закон порядка требует: понятие «закон» по материалам экспертной системы «византийское право и акты». К XXIII международному конгрессу византийских исследований. Белград, 22-27 августа 2016 г. Послесловие [43-95].

Серов B.B. На подступах к проблематике религиозных построек Юстиниана [96-105].

Сенина T.A. Эллинистические и светские мотивы в эпиграммах Кассии Константинопольской [106-146].

Сенина Т.А. (предисловие, перевод, комментарии) Житие преподобного Иоанна Психаита BHG 896 [147-176]. 
Рамазян А.С. Вопрос об иконопочитании в армяно-византийской полемике в конце $\mathrm{X}$ середине XI века [177-194].

Кузнецова Я.И. Свето-пространственная композиция храма монастыря Хоры в Константинополе. К постановке проблемы [195-210].

\section{Византийская Таврика}

Сорочан С.Б. Баптистерии раннесредневекового византийского Херсона: некоторые итоги изучения [211-219].

Могаричев Ю.М. К проблеме начальной истории готской епархии в Крыму [220-237].

\section{Паломничества. История и специфика}

Ларионов А.В., диакон. Афон глазами паломников: история и организация русского паломничества на Афоне до начала XX века [238-251].

Яшаева Т.Ю. Евлогии святой земли в византийском Херсоне [252-265].

Чхаидзе В.Н. Паломническая ампулаевлогия с Таманского городища [266-271].

«Вестник Волгоградского государственного университета.

Серия 4. История, Регионоведение, Международные отношения».

Тема: Византийское общество: история, право, культура

\section{Vol. 20. No. 3}

Византийская сфрагистика

Зоде K. (Германия) Византийские печати как средство презентации личностной и социальной идентичности [6-18].

Алексеенко H.A. «Тебя, хранителя моей души и моих, писаний, вырезываю на моей печати...» [19-29].

\section{Византийская историография и литература}

Валгрен Ш. (Норвегия) Историография средневизантийского периода: традиция, инновация и рецепция [30-37].
Афиногенов Д.Е. Славянский перевод жития преп. Евфимия Великого: наблюдения о языке и авторе [38-42].

Дробышев М.И. Известия о «немцах»


чинениях X-XII веков [43-47].

Византийское право и его влияние

Шаркич С. (Сербия) Влияние византийского права на средневековое сербское право [48-57].

Бубало Д. (Сербия) Время Законника Стефана Душана [58-78].

Идеология и духовная культура

в Византии

Бардашова T.Н. (Германия) Аспект визуального в системе идеологической пропаганды династии Великих Комнинов в Трапезундской империи (1204-1461) [79-91].

Барабанов Н.Д. Византийская народная антропология. Сила стопы и ее отражение в Житии св. Феодора Сикеота [92-99].

\section{Военная история Византии}

Золотовский В.A. Прония в военной организации Византии раннепалеологовского времени. Часть 1 [100-115]. Вторая часть статьи была опубликована в нетематическом номере 2016 г. Т. 21, № 2 [40-51].

\section{Критика и библиография}

Лысиков П.И. Библиография новейшей русскоязычной литературы (2010-2015 гг.) по проблемам военной организации Византийской империи [116-122].

2016. Vol. 21. No. 5

\section{Византийская сфрагистика}

Алексеенко Н.А. Новые сфрагистические находки в окрестностях византийского Херсона (к вопросу об адресатах корреспонденции) [6-18].

Йорданов И. (Болгария) Печати деятелей из «Алексиады», найденные в ВеликиПреславе [19-31]. 
История, культура, право

в византийских провинциях

Болгова А.М., Болгов Н.Н. Гимерий ритор и его школа в Афинах 2-й половины IV века [32-42].

Вин Ю.Я. «Земледельческий закон»источник правового регулирования и коллективного самосознания сельской общины в средневековой Византии [43-54].

Ендольщева Е.Ю., Чхаидзе В.Н. Лапидарная коллекция Таманского городища: варианты идентификации византийских рельефов [55-66].

Науменко В.E. К дискуссии о политикоадминистративном статусе Боспора в $\mathrm{X}$ ХІІ вв. [67-80].

\section{Война и византийское общество}

Капсальккова K.P. Образы войны в византийской литературе Х в.: Никифор Уран [81-91].

Мохов А.С. Византийская фема Хиос [92-101].

\section{Византийское православие}

Сенина T.А. (монахиня Кассия). Иоанн Грамматик и Лев Математик под прицелом ортодоксальной критики: параллели и исторический контекст [102-112].

Серов В.В., Крейдун Ю.А. Храмовое строительство в начальный период правления Юстиниана I (527-534 гг.) [113-120].

Стельник Е.В. Схватка с Харосом в византийском хтоническом мировоззрении [121-128].

\section{Византийская правящая элита при Палеологах}

Кущ Т.B. Политическая элита при Мануиле II Палеологе: эволюция придворной иерархии [129-136].

Лысиков П.И. Государство и церковь в Византии в период гражданской войны 13211328 гг.: император Андроник II Палеолог и патриархи Герасим I и Исайя [137-148].

Хроника научной жизни

Барабанов Н.Д. VIII Международный византийский семинар «ХЕP $\Sigma \Omega N O \Sigma$ बEMATA: империя и полис». Севастополь, Государственный историко-археологический музейзаповедник «Херсонес Таврический». 30 мая 4 июня 2016 г. [149-153].

\section{Критика и библиография}

Барабанов Н.Д., Маркарян Г.Г. Византия и Армения: метаморфозы военных связей (Мнение читателей о книге: Ayvazyan, A. The Armenian Military in the Byzantine Empire. Conflict and Alliance Under Justinian and Maurice [Text] / A. Ayvazyan. Alfortville: Editions Sigest, 2014. -152 p.) [154-158].

\section{Vol. 22. No. 5}

\section{Византийское православие}

Афиногенов Д.Е. Памфлет Арефы Кесарийского против Николая Мистика и императора Александра [6-15].

Вишняк М.А. Образ арсенитов в эпистолярном наследии патриарха Афанасия I Константинопольского [16-26].

Крейдун Ю.А., Серов В.В. Церковное строительство Юстиниана I по данным изданных им новелл [27-37].

\section{Византийская Таврика}

Айбабин А.И. О реформе системы управления владениями Византии в Крыму в последней четверти VI века [38-45].

Бочаров С.Г. О причинах конфликта между иерархами Херсонской, Сугдейско-Фульской и Готской митрополий за приходы южного берега Крыма (вторая половина XIV в.) [46-55].

Могаричев Ю.М. «Пещерный город» Эски-Кермен в описании А.С. Уварова [56-74].

Науменко В.Е. О византийской феме в Таврике в правление императора Никифора I Геника (802-811): критические замечания к гипотезе Тибора Живковича [75-85].

Хайрединова Э.А. Византийские кресты с инкрустацией из Юго-Западного Крыма [86-99].

\section{Византийская сфрагистика}

Алексеенко Н.А. Византийская Таврика во второй половине XI века и новая печать Льва Алиата из Херсона [100-111]. 
Кънев Н. (Болгария) Новая находка печати византийского стратига города Преслав [112-115].

Степаненко В.П. Две печати стратигов малоазийских фем из Северного Причерноморья [116-124].

\section{Византийский мир}

Матович T.M. (Сербия) К вопросу о разнице правового значения документа в византийском частном праве [125-131].

Тотоманова А.-М. (Болгария) Парабиблейские и библейские хронографические компиляции в Болгарии времени царя Симеона [На англ.] [132-141].

Боровков Д.С. Из истории византийской служилой аристократии: семья Халкуцев в $\mathrm{X}$ XI веках [142-148].

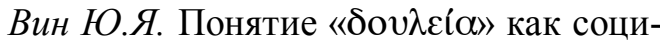
окультурный концепт в репрезентации византийских актов [149-161].

Крилянин Н. (Сербия) Титул самодержца (автократора) в Сербии и России: два пути развития византийского наследия [162-183].

Курышева М.A. К вопросу об узкой датировке рукописи трактата «De cerimoniis aulae Byzantinae» (Leipzig, Univ. Bibl. Rep. I17) [184-191].

Сенина Т.А. (монахиня Кассия). Афины versus Иерусалим? Отношение к научному знанию в Византии [192-204].

Чхаидзе В.Н. Лев Сгур - тиран и патриот. Правитель северо-восточного Пелопоннеса в начале XIII века [205-213].

\section{Византиноведение и философия: метаморфозы отношений}

Карчагин Е.В., Токарева С.Б., Яворский Д.Р. Понятие справедливости в истории ранневизантийской мысли (IV-VII вв.) [214-226].

\section{Византия и варвары}

Казанский М.М. (Франция), Мастыкова A.B. Варвары в городе: погребения германцев в городских некрополях Северного Иллирикума в ранневизантийское время [227-238].

Мастыкова А.В. Женский костюм германского происхождения в погребальном контексте ранневизантийских городов Северного Причерноморья (V-VI вв.) [239-251].

\section{Византия и война}

Золотовский В.A. Добровольцы в византийской армии позднего периода: к вопросу о телематариях [252-260].

Кущ T.B. Турецкая осада и штурм Константинополя 1422 года: военно-политический аспект [261-270].

Льсиков П.И. Письма Максима Плануда к Алексею Филанфропину и Мелхиседеку Акрополиту: проблемы источниковедения в контексте военно-политической ситуации в Византии в конце XIII века [271-287].

Мехамадиев Е.A. Армянская экспедиция императора Констанция II в 338/339 годах и войсковые подразделения экспедиционной армии Фракии на Ближнем Востоке: к вопросу о позднеримской военной организации в середине IV века [288-299].

Мохов А.С., Капсалькова К.Р. «Стратигисса среди них во всем предстала блеске»: роль знатной женщины в византийской провинциальной военной семье [300-310].

\section{Критика и библиография}

Барабанов Н.Д. Рец. на кн.: Caseau, В. Nourritures terrestres, nourritures célestes. La culture alimentaire à Byzance [Text] / B. Caseau. Paris : ACHCByz, 2015. - Liv, 346 p. - (College de France - CNRS. Centre de recherche d'histoire et civilization de Byzance. Monographies ; 46) [311-315].

2018. Vol. 23. No. 5

\section{Византийское светское и каноническое право}

Вин Ю.Я. Рецепция и транслитерация понятий и терминов византийского права: когнитивные аспекты систематизации [6-24].

Анашкин А.В. Жанровая природа канонико-правовых ответов патриарха Николая III Кирдиниата Грамматика [25-33].

Византийское наследие в проблемах богословия и философии XX века

Бирюков Д.С. Исследование рецепции паламизма в русской мысли начала XX в.: 
вопрос о философском статусе паламизма и варлаамизма, его решения и контекст [34-47].

Макаров Д.И. Трактат «Об образованности» Феодора Метохита и некоторые аспекты понятия созерцания у позднего Бергсона: к проблеме перекличек [48-59].

Сенина T.A. (монахиня Кассия). Византийская гимнография как источник учения о божественной энергии в богословии Иеросхимонаха Антония (Булатовича) [60-70].

\section{Византийская Таврика}

Айбабин А.И. О дате образования Крымской Готии [71-78].

Майко В.В. Салтово-маяцкая провинциально-византийская культура Крыма [79-87].

Хайрединова Э.А. Византийские перстни с надписью «Ф $\Omega \mathrm{C} Z \Omega H »$ из погребений крымских готов [88-104].

Могаричев Ю.М. Сюйреньская крепость в описании А.С. Уварова [105-118].

Степаненко В.П. А.А. Васильев о Крымской Готии второй половины $\mathrm{X}$ - начала XI века [119-130].

Чхаидзе В.Н. Византийская аристократия в Крыму и на Тамани: Агиостефаниты (XII в.) [131-137].

\section{Судьба Малой Азии в восприятии} византийцев палеологовского времени

Радич Радивой Джс. (Сербия) «Мизийский плен» в поздневизантийской литературе [На англ.] [138-146].

Кущ Т.В. Судьба утраченных территорий: взгляд византийского императора Мануила II Палеолога [147-156].

\section{Вопросы культуры Византии}

и Византийского Содружества Наџий

Болгова А.М. Орибасий и медицинская традиция Ранней Византии [157-168].

Шелудченко Ю.В., Болгов Н.Н. К вопросу об источниках и влияниях в сочинениях Кирилла Скифопольского [169-178].

Щавелев А.С. Датировка дипломатических писем Хасдая ибн Шапрута [179-185].

Стельник E.B. Харон в эпитафиях Иоанна Геометра (Кириота) [186-195].
Ендольиева Е.Ю., Дбар Д. (архимандpum). Архитектурная декорация и малые формы церкви в Дранде: новые данные [196-209].

Курышева М.А. Рукописи, составленные из писем: Анонимный учитель (Х в.), Михаил Пселл (XI в.) и Максим Маргуний (XVI в.) [210-218].

Польвянный Д.И. Возникновение и развитие древнеболгарской исторической апокалиптики в XI-XII веках [219-229].

\section{Война и общество в Византии. \\ История и историография}

Мохов А.С., Капсалькова К.Р. История византийской армии и военного искусства в неопубликованных работах М.Я. Сюзюмова 1930-1940-х годов [230-237].

Золотовский B.A. Византийский флот периода правления первых Палеологов (12591328) [238-250].

\section{Критика и библиография}

Чхаидзе В.Н. Рец. на кн.: Алексеенко, Н. А. Византийский Херсон VI-XIII столетий в памятниках сфрагистики. 1. Чиновники Херсона VIII-XI вв. [Текст] / Н. А. Алексеенко. Севастополь : Колорит, 2017. - 474 с. : 273 ил. [251-256].

Серов В.В., Крейдун Ю.А. Рец. на кн.: Turlej, S. Justiniana Prima. An Underestimated Aspect of Justinians Church Policy [Text] / S. Turlej. - Krakow : Jagiellonian University Press, 2017. - 244 p. - (Jagiellonian Studies in History ; vol. 7) [257-265].

\section{Vol. 24. No. 6}

\section{Византийская Таврика}

Айбабин А.И. Топоним Климаты в средневековом Крыму [6-17].

Майко B.B. Византийский комплекс первой половины XIII в. в портовой части Сугдеи [18-31].

Хайрединова Э.А. Перстни с изображением архангела Михаила конца VI - VII в. из Крыма [32-46].

Могаричев Ю.М., Ергина А.С. К вопросу о периодизации фресковых росписей пе- 
щерной церкви Южного монастыря Мангупа [47-63].

Мастыкова A.B. О находках металлических крестов на средневековом могильнике Горзувиты (Южный берег Крыма) [64-80].

Науменко B.E. О боспорской нефти Константина VII Багрянородного и византийском «греческом огне»: археологические свидетельства [81-89].

\section{Византийская сфрагистика}

Кънев Н. (Болгария) Византийская свинцовая печать нотария и авидика Константина, найденная в Болгарии [90-94].

Алексеенко Н.А. Ранневизантийское чиновничество в юго-западной Таврике в свете сфрагистических данных из Херсона и его округи [95-110].

Степаненко В.П. К иконографии св. воина-всадника в византийской сфрагистике XIIXIII вв. Св. Димитрий Солунский [111-120].

\section{Источниковедение Византии} и стран «Византийского Содружества»

Курышева М.А. Китонит Никита - заказчик «Библии Никиты» Х века [121-128].

Щавелев А.С. Об одной византийской риторической уловке для дезавуирования дипломатического прецедента (Const. Porph. Dai. 13.145-194 и Liud. Relatio. 55) [129-138].

Тотоманова A.-M. (Болгария) Отрывок «Хроники» Георгия Синкелла в славянском переводе [139-149].

Павлович Б.Д. (Сербия) Некоторые замечания к расхождениям в нарративе Георгия Акрополита и Феодора Скутариота [На англ. яз.] [150-172].

Польвянный Д.И. «Болгарская анонимная хроника»: опыт аналитической декомпозиции [173-183].

\section{Византия в войнах и конфликтах}

Казанский М.М. (Франция) Ранневизантийские шлемы типа Балденхейм в Поднепровье [184-197].

Золотухина Н.Е., Болгов Н.Н. Общество Северной Африки накануне войны Им- перии с вандалами и его отношение к Юстиниановской реконкисте [198-205].

Льсиков П.И. Социальная и политическая дестабилизация в Византии в начале XIV в.: причины и последствия [206-230].

Золотовский B.A. Фемная система и провинциальные вооруженные силы Византии раннепалеологовского периода (1259-1328 гг.) [231-244].

Куш T.B. Пираты Эгейского моря: морской разбой в Восточном Средиземноморье XV века [245-254].

\section{Византийское православие}

Грацианский М.В. Четвертый Вселенский собор и проблема первенства римского епископа [255-271].

Войтенко A.A. Приход или святцы? К вопросу о базовых элементах религиозной самоидентификации этноконфессиональных общин Христианского Востока [272-283].

Сенина Т.А. (монахиня Кассия). Житие св. Никифора Севазийского как иллюстрация восприятия иконоборческой эпохи византийцами в позднейшее время (с приложением перевода Жития) [284-296].

Макаров Д.И. Две заметки о понятии образованности у Феодора Метохита и в средневизантийской святоотеческой традиции [287-304].

Бирюков Д.С. Античная натурфилософия в византийской христологии: тема проникновения огня в железо [305-315].

Барабанов Н.Д. Волосы-змеи. К проблеме семантики византийских филактериев с «истерой» [316-330].

Стельник Е.В. Харон или Харос? Языковые группы и культурные уровни в византийском обществе IX-XII веков [331-337].

\section{Обзорь}

Анашкин А.В. «...Леонтия славного дочь»: историческая роль и творчество Элии Евдокии Августы в современной историографии (На материале книги Александровой Т. Л. «Византийская императрица Афинаида-Евдокия: жизнь и творчество в контексте эпохи правления императора Феодосия II (401450)». СПб. : Алетейя, 2018. 416 с.) [338-344]. 


\section{СБОРНИКИ СТАТЕЙ}

ПОАЕМОАОГОУ: сборник статей памяти профессора В.В. Кучмы /

сост. и общ. ред. Н.Д. Барабанова. -

Волгоград : Изд-во ВолГУ, 2012.

\section{Военная история Византии}

Серов В.B. «Стратегикон» и военные «заботы» императора Маврикия [16-30].

Сорочан С.Б. (Украина). Эволюция фортификации византийского Херсонеса/Херсона в VI-X вв. [31-57].

Цуриумия М. (Грузия). Эволюция пластинчатого доспеха в Грузии и Византии. Ламеллярные и чешуйчатые доспехи в X-XII вв. [58-95].

Золотовский B.A. «Константинопольская кампания» Михаила Палеолога: военноисторическая реконструкция [96-126].

\section{Византийская сфрагистика}

Алексеенко Н.А. Болгары в армии Романа IV Диогена: карьера Самуила Алусиана по данным сфрагистики [127-139].

Йорданов И. (Болгария). Печат на Григорий Бакуриани (Пакуриани) - архонт на архонтите [140-146].

Степаненко В.П. «Архонт архонтов» в византийской сфрагистике XI в. [147-159].

\section{Византийское источниковедение}

Гращианский М.В. Лев Диакон - читатель Лукиана [160-170].

Козлов А.С. К истории изучения Chronica Theodoricana [171-197].

Медведев И.П. Речь Георгия Гемиста Плифона на похоронах Клеопы Малатесты [198-206].

\section{Византийское православие}

Барабанов Н.Д. Народное почитание священных изображений в Византии. К постановке проблемы [207-214].

Герд Л.А. Перезахоронение останков человека в поствизантийском каноническом праве [215-226].
Коноводов И.В. Поминальные службы в системе материального обеспечения византийских монастырей XI-XII вв. [227-241].

Макаров Д.И. О пневматологических основаниях мариологии Феофана Никейского [242-258].

Малахов С.Н., Рудниикий Р.Р. Энколпионы и нательные кресты как источник по истории христианства Алании [259-294].

\section{Византийский социум}

Мохов А.С. К вопросу об эволюции придворных должностей в Византии X-XI вв.: доместик ипургии [295-303].

Вин Ю.Я. Социокультурный концепт собственности: по материалам византийских афонских актов [304-342].

Коробейников Д.А. Кыпчаки на восточных границах Никейской (Византийской) империи в XIII в. [343-358].

Поляковская М.А., Кущ, Т.В. Итальянцы глазами византийских авторов середины XIV в.: сфера культуры и политики [359-369].

Несмотря на то, что следующие сборники статей не были опубликованы в Волгограде, волгоградские исследователи принимали непосредственное участие в их издании.

\section{Власть, общество и церковь}

в Византии : сборник научных статей / сост. Н.Д. Барабанов, С.Н. Малахов. Армавир : б.и., 2007

Пенская Т.М., Пенской В.В. Формирование концепции «Богоизбранного» государства в раннехристианской идеологии [5-18].

Михалицын П.Е. О христологических аспектах, содержащихся в трагедии «XРI $\Sigma \mathrm{TO} \Sigma$ $\Pi A \Sigma X \Omega N »$ («страждущий Христос»), и их сопоставление с христологией свт. Григория Богослова [19-49].

Горайко А.B. Свт. Иоанн Златоуст как защитник права убежища Церкви [50-59].

Домановский А.Н. О «торгово-ремесленном департаменте» секрета эпарха города Константинополя в середине VII - IX в. [60-73].

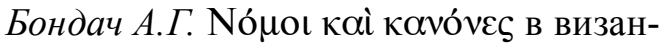
тийском церковном праве [74-88]. 
Кучма В.В. Методика боевой подготовки по «Тактике Льва»: господство принципов традиционализма [89-116].

Малахов С.Н. К истории алано-византийских отношений в 1045-1055 гг. [117-129].

Соколов Ю.Г. К истории Никейской империи: политическая роль высшей знати [130-142].

Власов А.В. Иосиф Исповедник, патриapx Константинопольский (1267-1275, 1282 1283) [143-164].

Деминщев М.С. К вопросу о заговоре Франгопула 1267 года [165-172].

Деминцев М.С. Церковный собор на Балканах 1277 года [173-182].

Пржегорлинский А.А. Аскетика св. Феолипта, митрополита Филадельфийского, и традиция поздневизантийского исихазма [183-217].

Патрин В.Г. К истории византийских молитвословий. Дидактика и эпиклеза как формообразуюшие принципы «молитвы Иисусовой» [218-223].

Гаген С.Я. Аллегория судебной тяжбы в антилатинской полемике (Никифор Григора и Варлаам Калабрийский) [224-230].

Барабанов Н.Д. Иеротопия и проблема «народной религиозности» в Византии (Некоторые соображения к развитию концепции) [231-238].

Лиман С.И., Сорочан С.Б. Деятельность императора Юстиниана I в оценках исследователей украинских земель Российской империи (1804-1885 гг.) [239-257].

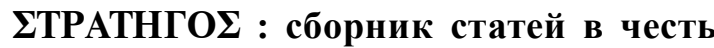

Владимира Васильевича Кучмы

/ отв. ред. С.Н. Малахов ;

сост. Н.Д. Барабанов, С.Н. Малахов. Армавир : б.и., 2008

Золотовский В.A. Владимир Васильевич Кучма как исследователь Военной истории Византии [5-18].

Барабанов Н.Д. Пастырь и паства. Отношения константинопольского патриарха Афанасия I и жителей византийской столицы в контексте проблемы «народной религиозности» [19-29].

Кучма В.В. Физиологические нормы и санитарно-гигиенические правила несения службы в вооруженных силах Византийской империи [30-61].

Литаврин Г.Г. К вопросу о значении налога натурой в Византии Х в. [62-70].

Макаров Д.И. Слава божия или слава ангелов? Некоторые аспекты полемики об ангелах на третьем этапе исихастских споров [71-94].

Медведев И.П. Византийская полемология в неопубликованном труде А.Н. Оленина (из истории науки) [95-103].

Перевалов С.М. Северо-восточная граница Римской империи по Notitia dignitatum (ок. 400 г.) [104-111].

Поляковская М.А. Влахерны - резиденция василевсов при Палеологах [112-125].

Пржегорлинский А.А. Митрополит Филадельфии Феолипт и византийская Церковь его времени [126-159].

Романчук А.И. О влиянии концепции на «прочтение» археологических отчетов [160-166].

Сорочан С.Б. Византийский преторий IX в. в «цитадели» Херсона [167-173].

Степаненко В.П. К датировке серебряной монеты (?) Никифора Вотаниата [174-179].

Шукуров Р.М. О нескольких восточных именах в антропонимике Трапезундской империи [180-186].

\section{Заметки}

Малахов С.Н. Моливдовул епископа Феодора из Алании [187-190].

\section{Речензии и библиография}

Соколов Ю.Г. Рец. на: Urbs capta. The Fourth Crusade and its Consequences. Paris, 2005 [191-199].

Основные научные труды В.В. Кучмы по истории Византии [200-204].

Заключение. Представленная в данной публикации информация на библиографическом материале отражает трудный путь становления и утверждения византиноведения в учебных заведениях Волгограда. В настоящее время изучение разных аспектов истории Византии продолжается на двух кафедpax Волгоградского государственного универ- 
ситета. Силами небольшой группы волгоградских византинистов при активной и благожелательной поддержке коллег из крупнейших центров отечественной науки византийский выпуск Вестника ВолГУ стал авторитетным, международно признанным изданием, что позволяет ему уверенно смотреть не только в средневековое прошлое, но и в ближайшее будущее.

\section{СПИСОК ЛИТЕРАТУРЫ}

1. Патрин, В. Г. Научная жизнь на Богословском факультете Царицынского Православного университета / В. Г. Патрин // Мир Православия. 2004. - Вып. 5. - С. 398-421.

2. Соколов, Ю. Г. Публикации по византиноведению в изданиях Волгограда: опыт аннотированной библиографии / Ю. Г. Соколов // Византийский временник. - 2007. - Т. 66 (91). - С. 295-302.

3. Список научный трудов В. В. Кучмы // Византийский временник. - 2011. - Т. 70 (95). C. 295-301.

4. Konovalov, A. A. Byzantium, the Christian Orient, and the Slavic World in the Publication of the Volgograd State University / A. A. Konovalov // Христианский Восток. - 2001. - Т. 2 (VIII). - С. 507-510.

5. Thomov, T. Vestnik Volgogradskogo gosudarstvennogo universiteta, serija 4: Istorija. Regionovedenie. Meždunarodnye otnošenija. Tema nomera: "Vizantijskoe obŝestvo: istorija, pravo, kul'tura" [Вестник Волгоградского государственного университета, серия 4: История. Регионоведение. Международные отношения. Тема номера:
«Византийское общество: история, право, культуpa»], t. 20, No. 3, 2015, t. 21, No. 5, 2016 and t. 22, No. 5, 2017 / T. Thomov // Études balkaniques. 2019. - LV/3. - P. 638-644.

\section{REFERENCES}

1. Patrin V.G. Nauchnaya zhizn na Bogoslovskom fakultete Tsaritsynskogo Pravoslavnogo universiteta [Scientific Life at the Theological Faculty of the Tsaritsyn Orthodox University]. Mir Pravoslaviya [The World of Orthodoxy], 2004, vol. 5, pp. 398-421.

2. Sokolov Yu.G. Publikatsii po vizantinovedeniyu v izdaniyakh Volgograda: opyt annotirovannoy bibliografii [Publications on Byzantine studies in Volgograd editions: an attempt of annotated bibliography]. Vizantiiskii vremennik, 2007, vol. 66 (91), pp. 295-302.

3. Spisok nauchnykh trudov V.V. Kuchmy [List of Scientific Works of V.V. Kuchma]. Vizantiiskii vremennik, 2011, vol. 70 (95), pp. 295-301.

4. Konovalov A.A. Byzantium, the Christian Orient, and the Slavic World in the Publication of the Volgograd State University. Khristianskiy Vostok [Christian East], 2001, vol. 2 (VIII), pp. 507-510.

5. Thomov T. Vestnik Volgogradskogo gosudarstvennogo universiteta, serija 4: Istorija. Regionovedenie. Meždunarodnye otnošenija. Tema nomera: "Vizantijskoe obŝestvo: istorija, pravo, kultura" [Vestnik Volgogradskogo gosudarstvennogo universiteta. Seriya 4. Istoriya. Regionovedenie. Mezhdunarodnye otnosheniya. Topic: "Byzantine society: history, law, and culture"], t. 20, No. 3, 2015, t. 21, No. 5, 2016 and t. 22, No. 5, 2017. Études balkaniques, 2019, vol. LV/3, pp. 638-644. 


\section{Information About the Authors}

Nikolay D. Barabanov, Candidate of Sciences (History), Associate Professor, Department of Russian and General History, Archaeology, Volgograd State University, Prosp. Universitetsky, 100, 400062 Volgograd, Russian Federation, byzbar@mail.ru, https://orcid.org/0000-0001-7873-5806

Vladimir A. Zolotovskiy, Candidate of Sciences (History), Head of the Department of Service and Tourism, Volgograd State University, Prosp. Universitetsky, 100, 400062 Volgograd, Russian Federation, zolotovskiy.azi@volsu.ru, https://orcid.org/0000-0002-4259-8851

Anastasiya V. Zykova, Chief Curator of the Museum Complex, Volgograd State University, Prosp. Universitetsky, 100, 400062 Volgograd, Russian Federation, nastenka96zykova@mail.ru, https://orcid.org/0000-0003-2701-2688

\section{Информация об авторах}

Николай Дмитриевич Барабанов, кандидат исторических наук, доцент кафедры отечественной и всеобщей истории, археологии, Волгоградский государственный университет, просп. Университетский, 100, 400062 г. Волгоград, Российская Федерация, byzbar@mail.ru, https://orcid.org/0000-0001-7873-5806

Владимир Алексеевич Золотовский, кандидат исторических наук, заведующий кафедрой сервиса и туризма, Волгоградский государственный университет, просп. Университетский, 100, 400062 г. Волгоград, Российская Федерация, zolotovskiy.azi@volsu.ru, https://orcid.org/0000-0002-4259-8851

Анастасия Валерьевна Зыкова, главный хранитель фондов Музейного комплекса, Волгоградский государственный университет, просп. Университетский, 100, 400062 г. Волгоград, Российская Федерация, nastenka96zykova@mail.ru, https://orcid.org/0000-0003-2701-2688 